\title{
Effects of Hot Deformation and Subsequent Austempering on the Mechanical Properties of Si-Mn TRIP Steels
}

\author{
Zhuang $\mathrm{LI}^{1)}$ and D. WU ${ }^{2)}$ \\ 1) State Key Laboratory of Rolling and Automation, Northeastern University, also Shenyang Institute of Aeronautical \\ Engineering, Shenyang 110034, P. R. China. E-mail: Lizhuang20047@163.com \\ 2) State Key Lab of Rolling and Automation, Northeastern University, P. O. Box 105, Shenyang, 110004, P. R. China.
}

(Received on June 23, 2005; accepted on October 14, 2005)

\begin{abstract}
In the present paper, effects of hot deformation and subsequent austempering on the mechanical properties of hot rolled Si-Mn TRIP steels were investigated. Thermomechanical controlled processing (TMCP) was conducted by using a laboratory hot rolling mill, in which three different kinds of finish rolling reduction, temperatures and austemperings with various isothermal holding duration were applied. The results have shown that polygonal ferrite, granular bainite and larger amount of stabilized retained austenite can be obtained by controlled rolling processes. Ultimate tensile strength, yield strength and total elongation increase with increasing the amount of deformation and decreasing finish rolling temperature due to the stabilization of retained austenite. Tensile strength and total elongation can reach the maximum values (791 MPa and $36 \%$, respectively), and isothermal holding $20 \mathrm{~min}$ at $400^{\circ} \mathrm{C}$ after hot deformation has been proved to be the optimum treatment.
\end{abstract}

KEY WORDS: hot deformation; austempering; TRIP steel; retained austenite; strength; ductility.

\section{Introduction}

In order to reduce vehicle weight without loss of safety, the automotive industry needs new formable high-strength steel sheets. Ttransformation-induced plasticity (TRIP) steels was introduced by Zackay et al. ${ }^{1)}$ in austenitic stainless steels. These TRIP steels have higher strength and better formability than conventional high-strength steels due to the transformation of metastable retained austenite present in the microstructure to martensite during forming of the steels. Recently, a new class of less expensive TRIP steel sheet not containing alloying elements of $\mathrm{Ni}$ and $\mathrm{Cr}$ but only $\mathrm{Si}$ and $\mathrm{Mn}$ has been developed. ${ }^{2-4)}$ The typical microstructure of these new TRIP steels consists of bainite, ferrite and a small fraction of retained austenite, which is obtained by carrying out a two-stage heat treatment, or austempering immediately after intercritical annealing.

High strength cold-rolled TRIP steel sheets by means of heat treatment have been extensively studied. However, it is troublesome process for steel sheets to be heat-treated on the run-out table. These TRIP steels are not well suited to the industrial practice for automotive manufacturing. Thermomechanical controlled processing (TMCP) eliminates the need for further heat treatments. The TRIP microstructures are obtained by direct hot rolling subsequent cooling to the bainite transformation temperature, at which temperature the sheet is coiled., $400^{\circ} \mathrm{C}$ is an optimum coiling temperature. ${ }^{6)}$ Hot rolled TRIP steels are more significant for industrial practice.

In the present study, controlled rolling processes were conducted by austempering to simulate coiling after hot rolling without subsequent heat treatment. Thermomechanical processing schedule was consistent with industrial processing in order to be applied in industrial production. Microstructure of various hot rolling processes and various isothermal holding time of austempering of $\mathrm{Si}-\mathrm{Mn}$ TRIP steels was observed in detail, and the mechanical properties of them were examined. Furthermore, the mechanism enhancing total elongation was discussed through studies of the mechanical stability and strain induced transformation behavior of retained austenite.

\section{Experimental Procedure}

In the present work, the steels were prepared as a vacuum melted $130 \mathrm{~kg}$ ingot followed by hot forging to produce a $80 \mathrm{~mm}$ thick slab. The $T_{\mathrm{nr}}, \mathrm{Ar}_{3}$ and $\mathrm{Ar}_{1}$, which denote the nonrecrystallization temperature, the start and finish temperatures of the austenite-to-ferrite transformation, respectively, were measured using a thermomechanical simulator by corresponding double-pass compression testing. The chemical composition and the critical temperatures of $\mathrm{Si}-$ Mn TRIP steels are given in Table 1.

First the slab was hot-rolled down to $20 \mathrm{~mm}$ by a $\phi 1250$ hot rolling mill, and then machined to form the plates of $17 \mathrm{~mm} \times 20 \mathrm{~mm} \times 650 \mathrm{~mm}$, and finally hot rolled down to various thickness steel sheets by a $\phi 180$ hot rolling mill. The processing schedule is shown in Fig. 1. After austenitizing at $1020^{\circ} \mathrm{C}$ for $300 \mathrm{~s}$, the specimens were deformed to Pass (1) and Pass (2) compressive strain in the austenite recrystallization region, and then deformed to Pass (3) and Pass (4) in nonrecrystallization region or the two-phase 
region (austenite plus ferrite), respectively (Table 2). Specimens were controlled rolled interval during four pass deformation in hot rolling to attain three different finish rolling temperatures of $700^{\circ} \mathrm{C}, 750^{\circ} \mathrm{C}, 800^{\circ} \mathrm{C}$. After finish rolling, specimens were cooled at $10 \mathrm{~K} / \mathrm{s}$ to the acceleratedcooling start temperature of $660-680^{\circ} \mathrm{C}$ in order to obtain an amount of polygonal ferrite. This was followed by a salt bath quench where the specimen was held isothermally for $20 \mathrm{~min}$ at $400^{\circ} \mathrm{C}(30 \%, 40 \%$ and $50 \%)$, to transform the austenite to bainite. To clarify the effect of the isothermal holding time, the duration $(40 \%)$ at the salt bath was set $2 \mathrm{~min}, 5 \mathrm{~min}, 10 \mathrm{~min}, 15 \mathrm{~min}, 20 \mathrm{~min}, 30 \mathrm{~min}, 60 \mathrm{~min}$ and $120 \mathrm{~min}$, respectively, and finish rolling temperature of these specimens was $750^{\circ} \mathrm{C}$. The specimen was then air cooled to room temperature. The surface temperature was measured by an infrared hand pyrometer throughout the experiment. The above thermomechanical processing schedule should be consistent with industrial processing, with the salt bath simulating coiling conditions used in hot strip rolling.

To study the mechanical properties of the present steel at room temperature, tensile tests were carried out. Transverse sections of the specimens before and after tensile testing for light optical microscopy (LOM) were polished and etched with $4 \%$ nital. These specimens for LOM were also colour etched using the LePera method. ${ }^{7)}$ With this etchant ferrite appears grey, bainite appears black, martensite and retained austenite appear white. The bainite fractions were assessed

Table 1. Chemical composition (wt $\%$ ) and measured transformation temperature $\left({ }^{\circ} \mathrm{C}\right)$ of steel used.

\begin{tabular}{ccccccccc}
\hline $\mathrm{C}$ & $\mathrm{Si}$ & $\mathrm{Mn}$ & $\mathrm{S}$ & $\mathrm{P}$ & $\mathrm{Al}$ & $A \mathrm{r} 1$ & $A \mathrm{r} 3$ & $T \mathrm{nr}$ \\
\hline 0.233 & 1.365 & 1.540 & 0.004 & 0.007 & 0.080 & $640^{\circ} \mathrm{C}$ & $780^{\circ} \mathrm{C}$ & $910^{\circ} \mathrm{C}$ \\
\hline
\end{tabular}

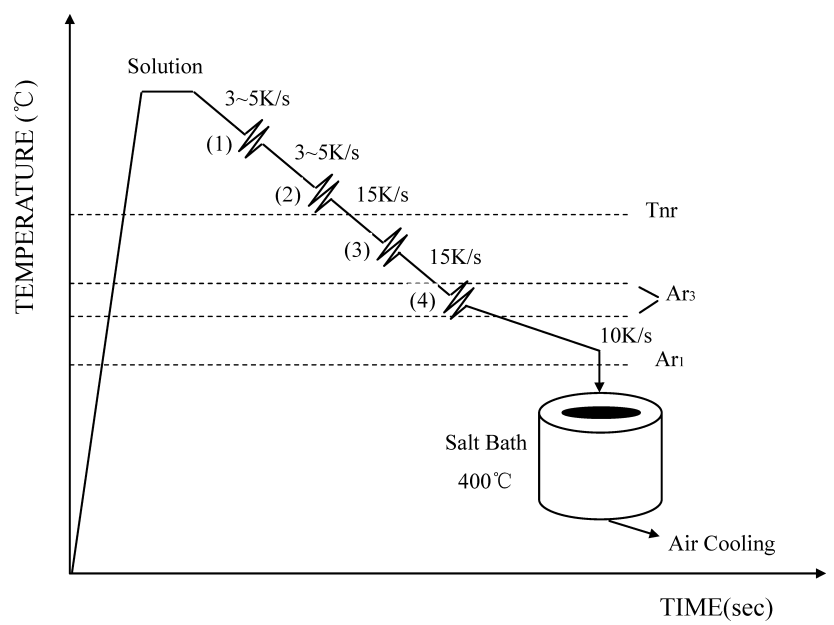

Fig. 1. Thermomechanical processing schedule. with image analysis software of Leica on colour etched cross sections of the specimens.

The microstructure was investigated further by scanning electron microscopy (SEM). At the same time, more detailed microstructural characterization was conducted by transmission electron microscopy (TEM). X-ray diffraction analysis was carried out to determine the volume fraction of retained austenite $\left(V_{\gamma}\right)$ with the modified Miller's method. ${ }^{8)}$

$$
V_{\gamma}=\frac{1.4 I_{\gamma}}{I_{\alpha}+1.4 I_{\gamma}}
$$

Where $I_{\alpha}$ and $I_{\gamma}$ are the integrated intensities of the $(200)_{\alpha}$ and $(211)_{\alpha}$ peaks and the $(200)_{\gamma},(220)_{\gamma}$ and $(311)_{\gamma}$ peaks, respectively.

\section{Results}

\subsection{Effect of the Amount of Deformation and Finish Rolling Temperature}

The amount of finish rolling deformation affects the microstructure and mechanical properties of $\mathrm{Si}-\mathrm{Mn}$ TRIP steels. Mechanical properties of the specimens dependence of finish rolling deformation at $700^{\circ} \mathrm{C}, 750^{\circ} \mathrm{C}$ and $800^{\circ} \mathrm{C}$ are shown in Fig. 2.

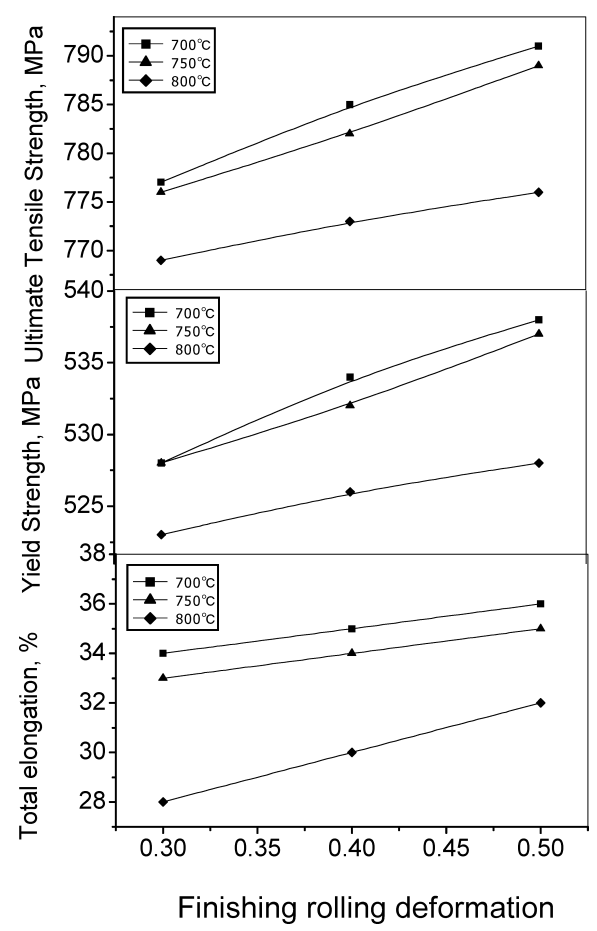

Fig. 2. Mechanical properties of the specimens dependence of finish rolling deformation at $700^{\circ} \mathrm{C}, 750^{\circ} \mathrm{C}$ and $800^{\circ} \mathrm{C}$, respectively.

Table 2. Deformation schedules.

\begin{tabular}{cccccc}
\hline Pass no. & Temperature $\left({ }^{\circ} \mathrm{C}\right)$ & Thickness $(\mathrm{mm})$ & \multicolumn{3}{c}{ Reduction (\%) } \\
& & & $(30 \%)$ & $(40 \%)$ & $(50 \%)$ \\
\hline$(1)$ & 970 & 11.0 & 45 & 45 & 45 \\
$(2)$ & 930 & 6.6 & 40 & 40 & 40 \\
$(3)$ & $810 \sim 860$ & 4.0 & 40 & 40 & 40 \\
$(4)$ & $700,750,800$ & $2.8,2.4,2.0$ & 30 & 40 & 50 \\
\hline
\end{tabular}



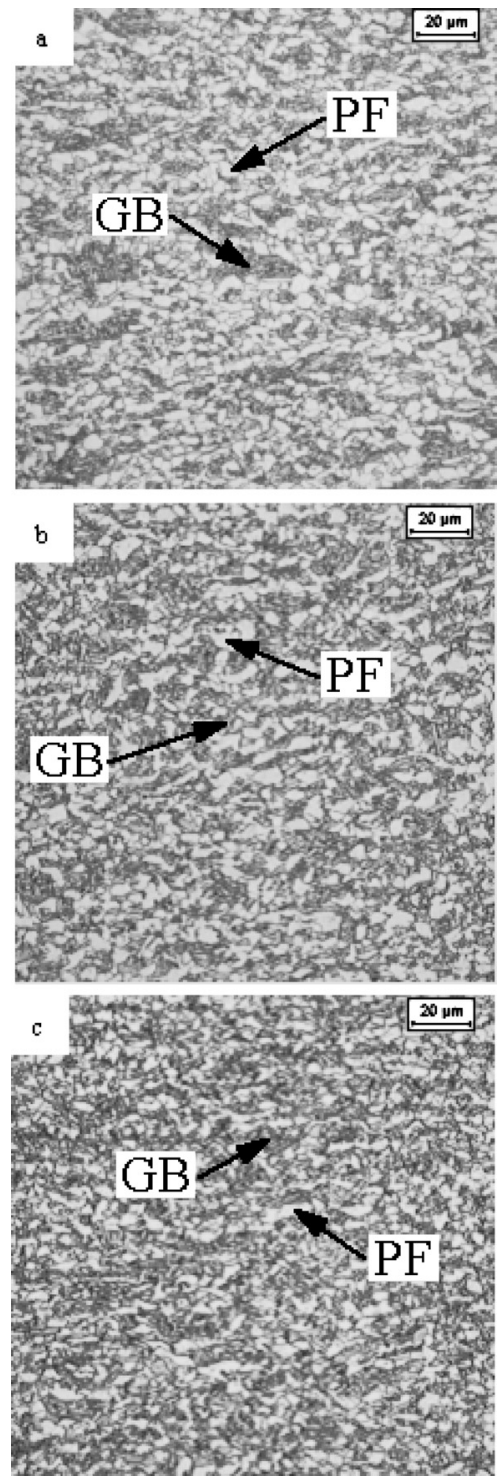

Fig. 3. Optical micrographs of $\mathrm{Si}-\mathrm{Mn}$ TRIP steels at different reduction of (a) $30 \%$, (b) $40 \%$, (c) $50 \%$ used at etchant $4 \%$ natal (PF: polygonal ferrite, GB: granular bainite).

From Fig. 2, mechanical properties of the specimens are dependent on finish rolling deformation showing the same trend at three different kinds of finish rolling temperatures. Ultimate tensile and yield strengths enhance obviously and total elongation increase gradually with increasing the amount of deformation at $700^{\circ} \mathrm{C}, 750^{\circ} \mathrm{C}$ and $800^{\circ} \mathrm{C}$.

The microstructures are composed of ferrite, granular bainite and retained austenite after $30 \%, 40 \%$ and $50 \%$. With increasing the deformation amount in finish rolling, the ferrite grain size decreased and the amount of granular bainite increased. LOM micrographs of the specimens $30 \%, 40 \%$ and $50 \%$ at finish rolling temperature of $700{ }^{\circ} \mathrm{C}$ are shown in Fig. 3.

The effects of finish rolling temperature on the microstructure and the mechanical properties of $\mathrm{Si}-\mathrm{Mn}$ TRIP steels are remarkable. In general, for the high strength and ductility of sheet steels, such as the similar chemical composition dual phase steels, total elongation is only about $20 \%$ when its tensile strength is about $800 \mathrm{MPa} .{ }^{9)}$ However, mechanical properties in the present TRIP steels are very high in most cases. Tensile strength of the specimens
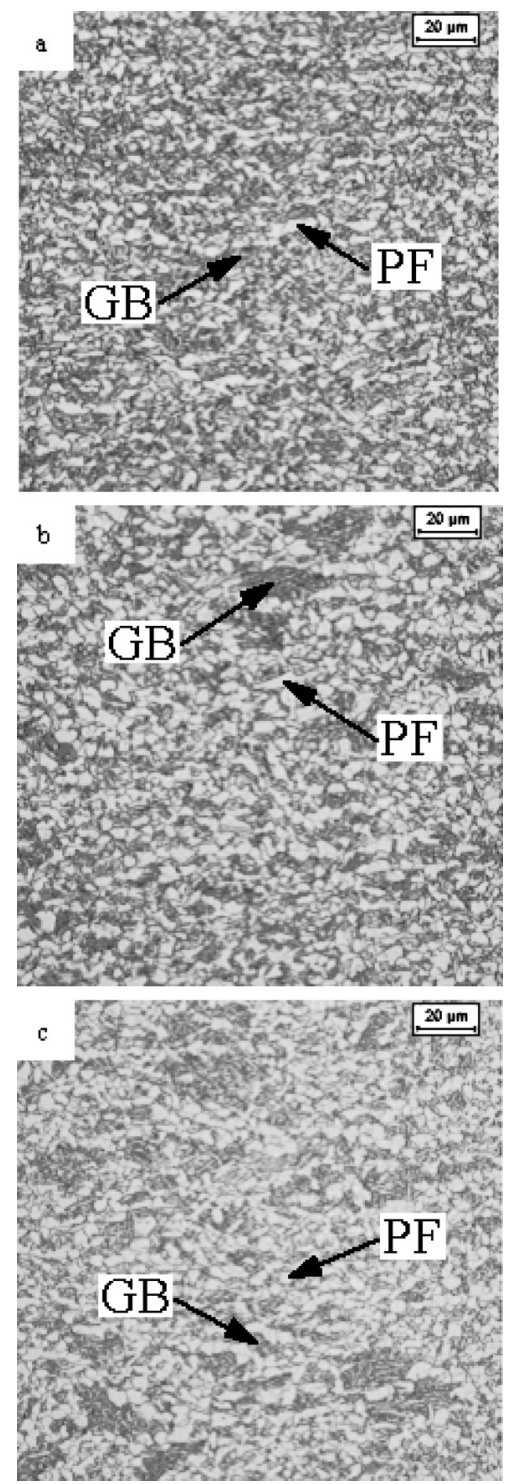

Fig. 4. Optical micrographs of the specimens at different finish rolling temperature of (a) $700^{\circ} \mathrm{C}$, (b) $750^{\circ} \mathrm{C}$, (c) $800^{\circ} \mathrm{C}$ used at etchant $4 \%$ natal (PF: polygonal ferrite, GB: granular bainite).

reached maximum values (791 $\mathrm{MPa})$, and total elongation of them reached maximum values $(36 \%)$ when they were deformed to $50 \%$ at finish rolling temperature of $700^{\circ} \mathrm{C}$. Mechanical properties of them increased with decreasing finish rolling temperature considerably.

The micrographs after different finish rolling temperature consist of polygonal ferrite, granular bainite and retained austenite in Si-Mn TRIP steels. The metallographic results of the specimens for $50 \%$ reduction at finish rolling temperature of $700^{\circ} \mathrm{C}$ is presented in Fig. 4. It can be seen from Fig. 4 that the ferrite grain size decreased, and the amount of granular bainite increased somewhat with decreasing finish rolling temperature for the present steels.

\subsection{Effect of the Isothermal Holding Time}

Figure 5 shows the relationship of ultimate tensile strength and total elongation with the isothermal holding time for the specimens deformed to $40 \%$ at finish rolling temperature of $750^{\circ} \mathrm{C}$.

In Fig. 5, mechanical properties were affected by austem- 


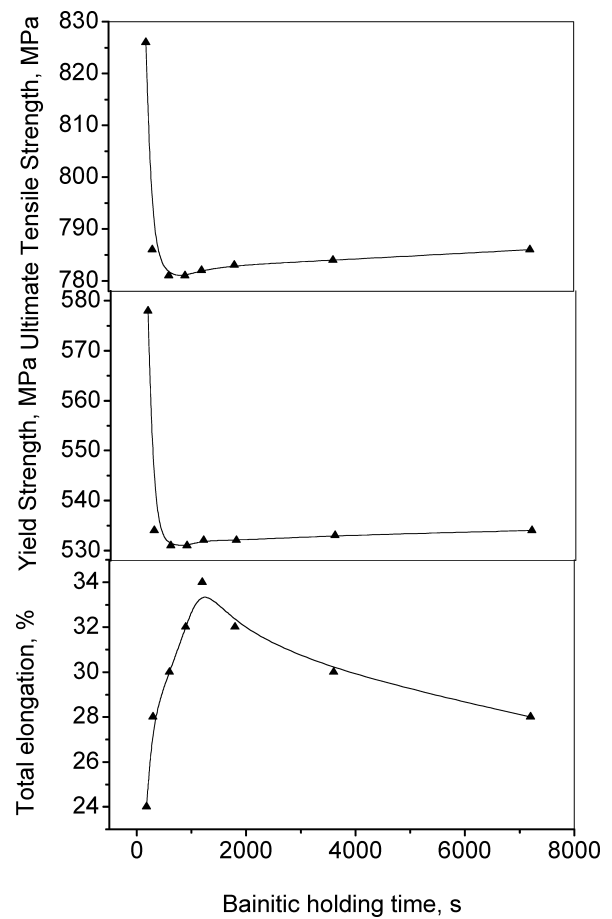

Fig. 5. Mechanical properties of the specimens at the various isothermal holding times.

pering after hot deformation. Total elongation increases with a increase of isothermal holding time, and reaches the peak values at $20 \mathrm{~min}$. At the peak time, the maximum values $(34 \%)$ of total elongation were obtained, and at the same time, tensile strength reached quite high values (782 MPa) for Si-Mn TRIP steels. The total elongation of the specimens is the minimum when it was held for $2 \mathrm{~min}$ in a salt bath after finish rolling, but it still reaches $25 \%$. When isothermal holding time increases up to $120 \mathrm{~min}$, the total elongation decreases in spite of tensile strength keeping increasing. The total elongation (TEL) of the specimen still comes to the high values $(28 \%)$ at too long holding duration.

When the present steels were austempered after hot deformation, the microstructures contained a lot of retained austenite, which can be identified in a Color etched LOM micrographs. Microstructures variations of the specimens which deformed to $40 \%$ at finish rolling temperature of $750^{\circ} \mathrm{C}$ holding duration for $20 \mathrm{~min}, 60 \mathrm{~min}$ and $120 \mathrm{~min}$ at $400^{\circ} \mathrm{C}$, are shown in Fig. 6.

In Fig. 6, the various phases appear as different colours under the microscope. White martensite-austenite islands are obvious when the specimens were held for $20 \mathrm{~min}$ (Fig. 6(a)). The amount of granular bainite increased sharply with increasing the holding time. Martensite-austenite islands are still present when holding duration was prolonged to $120 \mathrm{~min}$ although the amount of them is little (Fig. 6(c)). The bainite fraction reaches $65 \%$ when the specimen was held for $120 \mathrm{~min}$, and spare phases are polygonal ferrite and a bit of martensite-austenite islands (Fig. 6(c)). The relation between the bainite fractions and three different holding times of these specimens, is shown in Fig. 7.
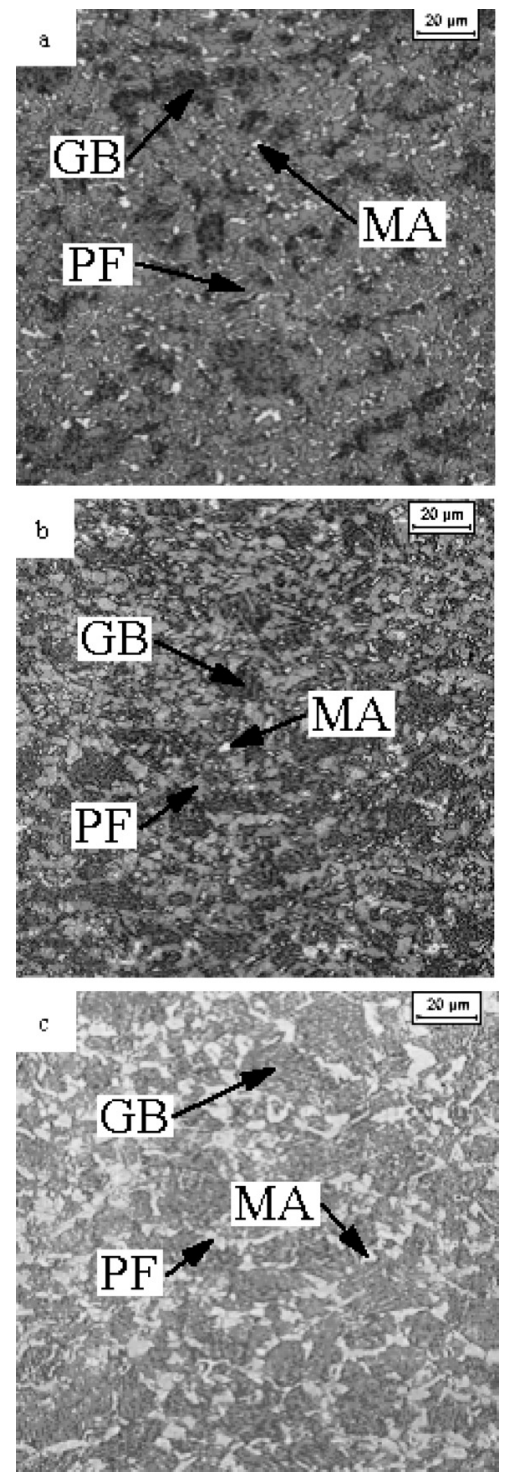

Fig. 6. Color-etched micrographs of steels (40\%) finish rolling deformation at $750^{\circ} \mathrm{C}$ for different holding times of (a) $20 \mathrm{~min}$, (b) $60 \mathrm{~min}$, (c) $120 \mathrm{~min}$ (PF: polygonal ferrite, MA: martensite-austenite islands, GB: granular bainite).

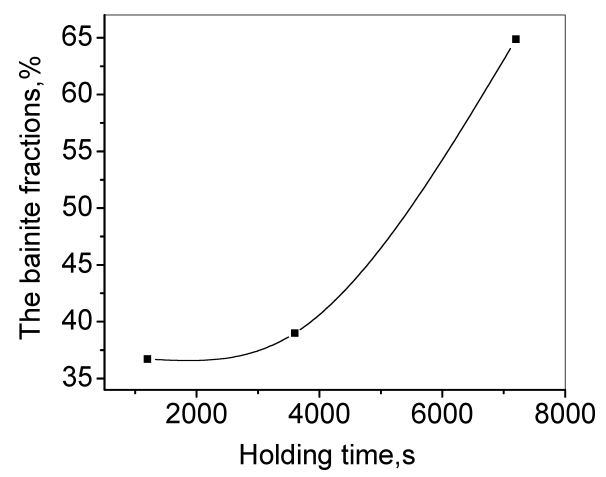

Fig. 7. The bainite fractions of the speciments at three holding times.

\subsection{The Electron Microscopy Microstructural Char- acterization}

All constituents (polygonal ferrite, granular bainite and retained austenite) can clearly be seen by scanning electron microscope. Morphologies of the specimens bv different thermomechanical processings are similar to some extent. 


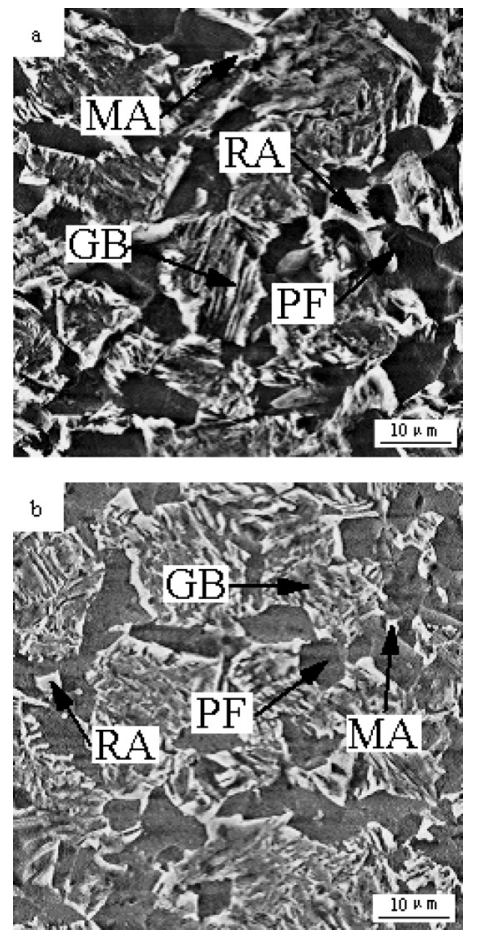

Fig. 8. SEM micrographs of the specimens (a) before and (b) after tensile testing (PF: polygonal ferrite, RA: retained austenite, MA: martensite-austenite islands, GB: granular bainite).

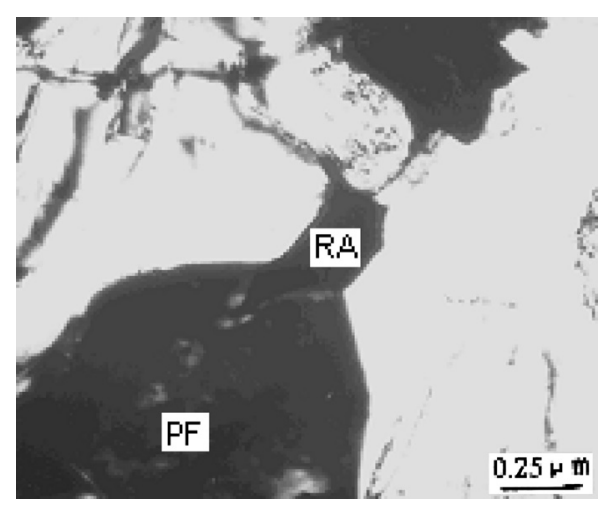

Fig. 9. TEM micrographs of steel $(40 \%)$ after finish rolled at $750^{\circ} \mathrm{C}$ (PF: polygonal ferrite, RA: retained austenite).

Figure 8 shows typical SEM micrographs of steel (40\%) after finish rolling at $750^{\circ} \mathrm{C}$.

Ferrite (black), retained austenite (grey), martensiteaustenite islands (white) and granular bainite can be seen in Fig. 8. Granular bainite contains some islands that are distributed in the ferrite matrix, and usually comprised of retained austenite and/or martensite/austenite constituents. Larger amount of austenite (grey) can be retained for the specimens before tensile testing, and martensite-austenite islands (white) increased obviously after tensile testing.

The presence of retained austenite in Si-Mn TRIP steels, which could not be resolved by optical microscopy, was confirmed by transmission electron microscopy (TEM) studies. Figure 9 shows TEM micrograph for $40 \%$ reduction and finish rolling at $750^{\circ} \mathrm{C}$ and isothermal holding $20 \mathrm{~min}$ in the specimen.

In Fig. 9, the particles of retained austenite are quite fine, and less than about $0.3 \mu \mathrm{m}$ in size.

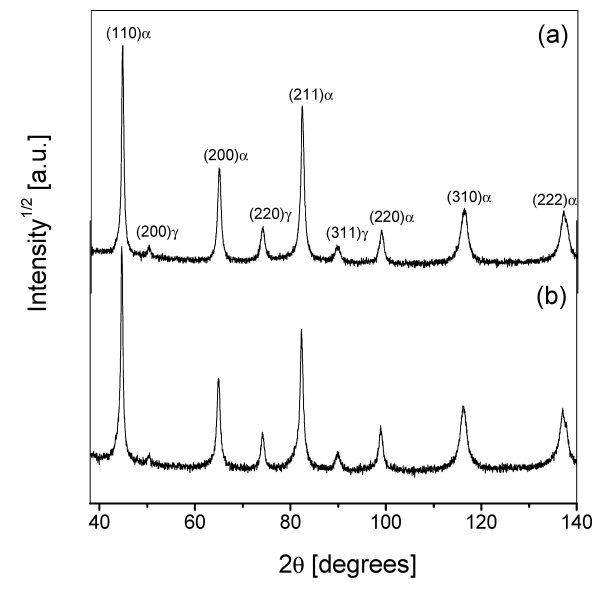

Fig. 10. X-ray diffraction patterns of steel (40\%) after finish rolled at $750^{\circ} \mathrm{C}$ (a) before tensile testing, (b) after tensile testing.

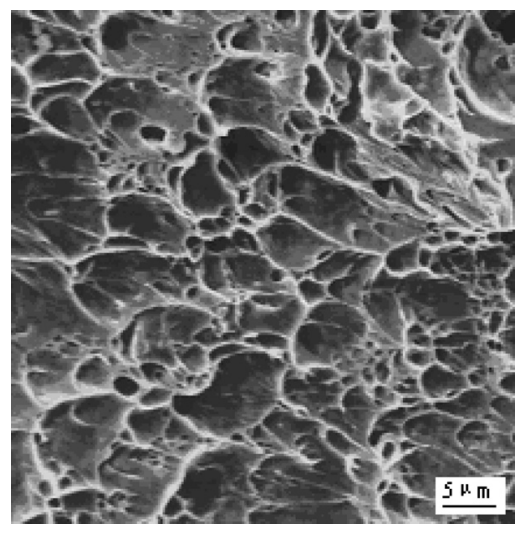

Fig. 11. The fracture morphology of steel $(40 \%)$ after tensile testing.

Retained austenite volume fraction before and after tensile testing for the steel $(40 \%)$ finish rolled at $750^{\circ} \mathrm{C}$ and isothermally held for $20 \mathrm{~min}$ was determined by the X-ray diffraction patterns, as shown in Fig. 10. After tensile testing, the amount of retained austenite at necking of the specimen decreases from 20 to $14 \%$.

When all the specimens were broken after tensile test, their fracture appearances exhibit ductile characteristics. The fracture morphology of the same specimen as described above is presented in Fig. 11. In Fig. 11, a lot of dimples were found.

Increasing the holding duration from 2 to $120 \mathrm{~min}$ at $400^{\circ} \mathrm{C}$ for the steels $(40 \%)$ resulted in microstructure variation. Spherical cementite can be found within the bainitic ferrite plates in steels $(40 \%)$ which held for $120 \mathrm{~min}$ at $400^{\circ} \mathrm{C}$ after finish rolled at $750^{\circ} \mathrm{C}$, as shown in Fig. 12 .

\section{Discussion}

\subsection{The Formation of the Ferrite and Bainite}

In this study, the specimens were subjected to four pass deformation in hot rolling, latter two pass deforming at temperatures below the austenite nonrecrystallization temperature (Pass (3) and Pass (4) reduction) resulted in the pancaking of austenite, ${ }^{5)}$ which altered the substructure of the austenite prior to transformation. ${ }^{10)}$ Specimens were deformed at the intercritical region when finish rolling tem- 


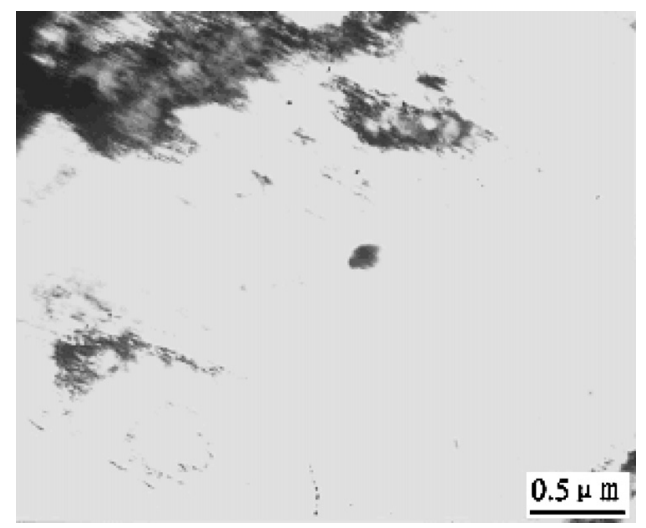

Fig. 12. TEM micrographs showing the formation of cementite.

peratures were $700^{\circ} \mathrm{C}$ and $750^{\circ} \mathrm{C}$. Austenite grains were stretched due to deformation, the deformation bands in austenite produced by the intercritical deformation divided an austenite grain into several parts with smaller sizes. ${ }^{11)} \mathrm{A}$ larger reduction can lead to more deformation bands within austenite grains and more ferrite fragments, these became preferred sites for ferrites. When the austenite transformed to ferrite, ferrite grains nucleated not only on austenite grain boundaries but also within grains. Besides, ferrite can be also produced through the deformation-induced transformation during deformation rather than after deformation.

Thermomechanical controlled processing (TMCP) has played an important role in the present steels. The steels were cooled at $10 \mathrm{~K} / \mathrm{s}$ to temperature of 660 to $680^{\circ} \mathrm{C}$ after finish rolling, and austenite could transform to ferrite in the two-phase region (austenite plus ferrite) because time was enough for the transformation. This is the reason why a good deal of polygonal ferrite appeared (Figs. 3, 4, 6, 8).

Austenite transformed to bainite after the steel was placed into a salt bath for quenching, in which it was held isothermally for a predetermined duration at $400^{\circ} \mathrm{C}$ (this temperature was the optimum temperature for maximizing the retained austenite volume fraction). ${ }^{6}$ A lot of granular bainite were obtained by the salt bath quench in the present steel, because $400^{\circ} \mathrm{C}$ is a upper region of the upper bainite reaction temperature as upper bainite appears at $350^{\circ} \mathrm{C}$ in $\mathrm{Si}-\mathrm{Mn}$ bainitic steels. ${ }^{12)}$ Granular bainite is characterized by the absence of carbides, the presence of isolated regions of high-carbon austenite, and martensite between crystals of bainitic ferrite, which have a grain or plate morphology. ${ }^{13)}$ Islands of martensite/austenite are randomly distributed in the ferrite matrix (Figs. 3, 4, 6, 8). The amount of granular bainite increased obviously with increasing the holding duration in a salt bath in the present steels (Figs. 6, 7).

According to the experimental results, ferrite grain has been refined with increasing finish rolling reduction. A decrease in the grain size generally leads to an increase in the ultimate tensile strength and yield strength through the Hall-Petch relationship:

$$
\sigma_{\mathrm{y}}=K+k_{\mathrm{y}} d^{-1 / 2}
$$

Where $\sigma_{\mathrm{y}}$ is the lower yield stress, $K$ is the material constant, $k_{\mathrm{y}}$ is the strengthening coefficient, and $d$ is the ferrite grain size. ${ }^{14)}$ The high strength was obtained when the specimen was deformed to $50 \%$ at finish rolling temperature of $700^{\circ} \mathrm{C}$, this is likely related to refining the ferrite grain.

As mentioned previously, the amount of granular bainite has increased with finish rolling reduction. Granular bainite contains some islands that are distributed in the ferrite matrix, and these islands consist of retained austenite and/or $\mathrm{M} / \mathrm{A}$ constituents. The islands possess the effect of the multiphase strengthening. Therefore, the presence of these granular bainite containing dispersed MA islands makes a contribution to the high strength and ductility of the present TRIP steels.

\subsection{Retained Austenite Formation Characteristics}

The present steel contains alloying elements of Si, which dissolves in ferrite as a ferrite-formation element when polygonal ferrite forms, which raises the chemical potential of carbon in ferrite and enhances carbon diffusion into austenite. When being held at bainite transformation range, austenite could be transformed to bainitic ferrite, Si efficiently suppresses the formation of cementite because it does not dissolve in cementite, and carbon diffuses into austenite further. The remaining austenite is enriched of carbon in the end. An increase of carbon content in retained austenite due to $\mathrm{C}$ enrichment results in the decrease of the Ms temperature of austenite. As a result, larger amount of austenite with carbon enrichment survives the final cool to ambient temperature in $\mathrm{Si}-\mathrm{Mn}$ TRIP steels (Figs. 3, 4, 6, 8).

After deformation, the prior austenite grains are fragmented by deformation bands. As a result, the small particles of austenite tend to be stable, as shown in Fig. 9. It has been reported that smaller austenite size helps the retention of austenite instead of martensite formation. ${ }^{15)}$ These fine islands of austenite that are trapped between the plates of bainitic ferrite in a sheaf are much more stable because of the higher carbon concentration and also because of the physical constraint to transformation due to the close proximity of plates in all directions. ${ }^{16)}$ The particles of retained austenite is very small, and small grain sizes hinder the plastic accommodation accompanying the formation of the martensitic plates. ${ }^{17)}$ The stability of retained austenite against the martensitic transformation is greatly increased, and a large amount of stabilized austenite is retained.

Recovery of austenite can only occur partially and recrystallization can not when all of the specimens deformed at temperatures below the austenite nonrecrystallization temperature. However, relatively high dislocation density and a great deal of strain accumulation within the austenite grains can be obtained in specimens deformed at $700^{\circ} \mathrm{C}$ and $750^{\circ} \mathrm{C}$. The amount of strain energy accumulation increases with decreasing of finish temperature and increasing of finish rolling reduction. The density of dislocations in austenite increases, because recrystallization can not occur when the steel is deformed in the nonrecrystallized austenite. A higher dislocation density of retained austenite hinders the growth of the martensitic plates. ${ }^{18)}$ Finally, retained austenite is stabilized considerably for the martensitic transformation in the present steels.

As mention above, high content of $\mathrm{C}$, small particles and high dislocation density of the retained austenite result in the greatly increased stability of residual austenite, causing the $M$ s temperature to be below room temperature. The sta- 
bility of the retained austenite will influence the mechanically induced transformation of retained austenite under straining at room temperature, and play an important role in enhancing the elongation in the present steel.

\subsection{Transformation-induced Plasticity during Tensile Testing}

Larger amount of stabilized austenite were retained by hot deformation and subsequent austempering in the present steels. As a result, the strain-induced transformation to martensite from the retained austenite occurs gradually when the steel is deformed during tensile test. SEM micrographs (Fig. 8) and X-ray diffraction results can confirm this transformation phenomenon (Fig. 10). This transformation is accompanied by a volume expansion and resulted in a localized increase of the strain hardening coefficient during straining, which delays the onset of necking and ultimately leads to a higher uniform and total elongation, ${ }^{3)}$ Moreover, void initiation at the matrix/second phase interface is suppressed because severe local stress at the interface is expected to be relaxed by isotropic expansion on strain-induced martensite transformation. ${ }^{4)}$ At the same time, transformation-induced plasticity (TRIP) of retained austenite is realized. Therefore total elongation has been improved considerably (Fig. 11), and desired mechanical properties are produced via hot deformation and subsequent austempering (Figs. 2, 5).

Retained austenite appeared as small, stable islands, as shown in Fig. 9. The second phases such as retained austenite or bainite are distributed in a soft ferrite matrix in the present microstructure. Retained austenite transforms to martensite during deformation. The martensitic transformation is accompanied by shear and dilatational deformation that induce plastic deformation of the surrounding ferritic matrix. ${ }^{19)}$ Plastic deformation at first occurs in the softer phase, and then the harden phase only begins to deform when the softer phase has strain hardened sufficiently to transfer load. The hard martensite phase under straining can stimulate the formation of new mobile dislocations in a soft ferrite matrix and decrease the yield strength. ${ }^{20)}$ Therefore, the low yield strength is exhibited although their ultimate tensile strength and total elongation are high in $\mathrm{Si}-\mathrm{Mn}$ TRIP steels (Figs. 2, 5).

The stability of austenite in the present steel is established by austempering after hot deformation. The steel was held in the salt bath after hot deformation. Increasing the holding duration from 2 to $20 \mathrm{~min}$ at $400^{\circ} \mathrm{C}$ resulted in the increase of the amount of bainitic ferrite, which resulted in the increase of carbon concentration in the remaining austenite due to the carbon rejection from bainitic ferrite. Thereby, the stability of the remaining austenite was increased, and the TRIP effects were striking. Therefore, the mechanical properties of steels $(40 \%)$ reached the maximum values (Fig. 5). A further increase in the holding duration (i.e., beyond $120 \mathrm{~min}$ in the present case), however, resulted in a decrease of carbon concentration in the remaining austenite. This is because prolonged holding leads to cementite precipitation, which destabilizes the austenite. The cementite formation within steels $(40 \%)$ has been confirmed in the TEM micrograph of Fig. 10 already. The total elongation decreases relatively when holding $120 \mathrm{~min}$ at $400^{\circ} \mathrm{C}$, but it still exceeds $28 \%$ (Fig. 5). Strain induced transformation to martensite of retained austenite and transformation induced plasticity (TRIP) occurs when the steel is strained because retained austenite exists in the microstructure all the time although the amount of it decreases (Figs. 6, 10). Therefore, the mechanical properties of the present steels keep the relatively high constant value with holding time prolonged.

\section{Conclusions}

Effects of hot deformation and subsequent austempering on the mechanical properties of hot rolled $\mathrm{Si}-\mathrm{Mn}$ TRIP steels can be summarized as follows:

(1) Polygonal ferrite, granular bainite and larger amount of stabilized retained austenite can be obtained by hot deformation and subsequent austempering result in excellent mechanical properties in the present TRIP steels.

(2) The effect of thermomechanical processing on the mechanical properties is remarkable in the present steels. Ultimate tensile strength, yield strength and total elongation increase with increasing of the amount of deformation and decreasing of finish rolling temperature for the stabilization of retained austenite due to $\mathrm{C}$ enrichment, refined particle and higher dislocation density, and tensile strength and total elongation reach the maximum values (791 MPa and 36\%, respectively) at finish rolling temperature of $700^{\circ} \mathrm{C}$ for $50 \%$ reduction.

(3) The mechanical properties of the present steels keep the relatively high constant value at the various isothermal holding duration. Total elongation reaches the maximum values at $20 \mathrm{~min}$. A further increase in the holding duration resulted in cementite precipitation, which destabilizes the austenite, and therefore TRIP effect is weak.

\section{Acknowledgement}

This work was supported by the National Natural Science Foundation of China (No.50334010). The authors (Z. Li) also acknowledges the support of the Doctor Degree Thesis Subsidization Item of Northeastern University (No.200302).

\section{REFERENCES}

1) V. F. Zackay, E. R. Parker, D. Fahr and R. Bush: Trans. Am. Soc. Met., 60 (1967), 252-259.

2) Y. Sakuma, O. Matsumura and H. Takechi: Metall. Trans. A, 22A (1991), 489.

3) M. D. Meyer, D. Vanderschueren and B. C. D. Cooman: ISIJ Int., 39 (1999), 813.

4) K. Sugimoto, M. Kobayashi and S. Hashimoto: Metall. Trans. A, 23A (1992), 3085.

5) A. Z. Hanzaki, P. D. Hodgson and S. Yue: ISIJ Int., 35 (1995), 324.

6) E. V. Pereloma, I. B. Timokhina and P. D. Hodgson: Mater. Sci. Eng., 273 (1999), 448.

7) E. Girault, P. Jacques, P. Harlet, K. Mols, J. Van Humbeek, E. Aernoudt and F. Delannay: Mater. Charact., 40 (1998), 111.

8) R. L. Miller: Trans. Am. Soc. Met. 57 (1964), 892.

9) Y. Son, Y. K. Lee, K. T. Park, C. S. Lee and D. H. Shin: Acta Mater, 53 (2005), 3125.

10) S. Yue, A. DiChiro and A. Z. Hanzaki: JOM, 49 (1997), 59.

11) T. Tanaka: Int. Met. Rev., 4 (1981) 185.

12) H. K. D. H. Bhadeshia and D. V. Edmonds: Metall. Trans. A, 10A (1979), 895. 
ISIJ International, Vol. 46 (2006), No. 1

13) S. W. Thompson, D. J. Colvin and G. krauss: Metall. Trans. A, 21A (1990), 1493.

14) D. V. Edmonds and R. C. Cochrane: Metall. Trans. A, 21A (1999), 1527.

15) N. C. Goel, J. P. Chakravarty and K. Tangri: Metall. Trans. A, 18A (1987), 5.

16) M. Takahashi and H. K. D. H. Bhadeshia: Mater. Trans. JIM, 32
(1991), No. 8, 689

17) C. L. Magee: Metall. Trans., 2 (1971), 425.

18) K. Tsuzaki, S. Fukasaku, Y. Tomota and T. Maki: Mater. Trans. JIM, 32 (1991), 28.

19) D. Bourell and L. Rizk: Acta Metall., 31 (1983), 17.

20) T. Kvackaj and I. Mamuzic: ISIJ Int., 38 (1998), 1270. 